\title{
NASTAVA MLAĐIH KNJIŽEVNIH ŽANROVA NA AZERBEJDŽANSKOM UNIVERZITETU JEZIKA
}

\section{Sažetak}

Kriminalistički roman predstavlja jednu od produktivnijih grana savremene svetske književnosti i kao takav daje veliki doprinos teoriji književnosti, proširujući njene granice i mogućnosti. Moderan detektivski roman nastoje 40-ih godina XIX veka u Americi i bio je uslovljen socijalno-moralnim činiocima. Ova vrsta književnog dela donela je mnogo novih i zanimljivih promena u azerbejdžanskoj književnosti.

Čingiz Abdulajev je tvorac političkog detektivskog romana, zasnovanog na realnim činjenicama i događajima. Zahvaljujući njegovim delima napisano je 60 filmskih scenarija, snimljeno sedam filmova i dve serije. Pisanje Čingiza Abdulajeva karakteriše aktuelnost, sveobuhvatnost, realni istorijski i politički događaji. Danas je Čingiz Abdulajev jedan od najpoznatijih svetskih autora detektivskih romana, upravo zbog toga želimo da i srpske čitaoce, upoznamo sa njegovim stvaralaštvom.

Ključne reči: Azerbejdžan, kriminalistički roman, dastana, Čingiz Abdulajev, Džamšid Amirov.

Kriminalistički roman predstavlja jednu od produktivnijih grana savremene svetske književnosti i kao takav daje veliki doprinos teoriji književnosti, proširujući njene granice i mogućnosti. U njemu se opisuju kriminalni događaji poput ubistava, terora, pohlepe vladajuće klase, različite socijalne nedaćekoje predstavljaju vodeći problem savremenog društva, uz istovremeno dočaravanje otpora i žestoke ljudske borbe protiv gore navedenih pojava. Ove i druge karakteristike detektivskog žanra mogu se naćiu drevnim istočnjačkim spisima poputAveste, u bajkama „Hiljadu i jedna noć", u različitim formama narodnih običaja i legendi. Moderan detektiv-

lala_majidova@hotmail.com 
ski roman nastoje 40-ih godina XIX veka u Americii bio je uslovljen socijalno-moralnimčiniocima.

Ova vrsta književnog dela donela je mnogo novih i zanimljivih promena u azerbejdžanskoj književnosti. Žanr se obnovio, razvio i dao nove oblike. Prateći genezu i razvoj azerbejdžanskog kriminalističkog romana može se reći da su njegovi koreni čvrsto utemeljeni u svetskoj književnosti. On vodi poreklo od mitova, dastana (priča) Nizami Gjandževia, u kojima preovladava tematika pravičnosti carskog i božijeg suda. $U$ zavisnosti od svrhe, teme i kompozicije, azerbejdžansku detektivsku književnost moguće je podeliti na tri osnovna pravca: policijski, politički i špijunski roman.

Tokom poslednje decenije ova grana književnosti uživa stalnu pažnju čitalaca. Štampaju se ogromni tiraži knjiga, kako prevedenih, tako i azerbejdžanskih autora. Čuvene krimiće čitaju praktično svi i ta sveobuhvatnost čitalačke auditorije čini ga neprikosnovenim ideološkim oružjem protiv zla i nasilja ${ }^{1}$.

Utemeljivačem špijunskog i policijskog romana u Azerbejdžanu smatra se Džamšid Amirov, 50-ih, 60-ih godina prošlog veka. Međutim, ono što nas konkretno zanima je pravac koji uživa veliki uspeh ne samo u republici, već i u inostranstvu, a to je „politički krimić“.

Čingiz Abdulajev je tvorac političkog detektivskog romana, zasnovanog na realnim činjenicama i događajima. Kao i u drugim oblicima detektivske književnosti, centralnu radnju zauzima zločin i njegova istraga. Međutim, za razliku od policijskog romana u kojem zločin ima lični karakter, u političkom on se uzdiže na jedan globalni nivo kao što je međunarodna trgovina drogom i ljudima, politički prevrati i afere, ratni događaji i dr. Stoga se on i smatra poludokumentarnom prozom.

Čingiz Abdulajev je rođen u Bakuu 1959. godine. Stekao je tri visoka obrazovanja, govori šest stranih jezika. U periodu 1982-1983. završavao je viši kurs KGB Sovjetskog Saveza. Radio je u Ministarstvu odbrane, izvršavao zadatke $u$ inostranstvu kao deo specijalne jedinice posebne namene, radio je u Poljskoj, Nemačkoj, Belgiji, Angoli, Rumuniji i Avganistanu. Major u ostavci, nosilac niza vladinih nagrada, doktor pravnih nauka. Narodni pisac i član Saveta starešina Udruženja književnika Azerbejdžana, član Upravnog

1 Jliyeva N. Detektiv janr Azarbaycan yeni nasri kontekstinda // Elmi araşdırmalar, 2002, br. 1-2, str. 124-126

2 Bavin S. Predgovor/ Inostrani detektivski roman HH veka. M.: 1991, str. 10 
odbora Međunarodnog Fonda za saradnju i partnerstvo Crnog i Kaspijskog mora. Profesor na katedri za kriminalističko pravo Azerbejdžanskog međunarodnog Univerziteta, član Komisije za dodelu državnih nagrada Republike Azerbejdžan iz oblasti nauke, kulture i književnosti. Od jula 2011. godine član je Koordinacionog Saveta Azerbejdžanaca u svetu.

Dodeljena mu je nagrada nemačkih književnika „Za doprinos razvoju evropskog romana" (2004). Počasni je građanin grada Trgu-Kerbunešti, Rumunija (2011). (Bez obzira na to, što su mu 1986. godine zabranili ulazak u Rumuniju, i što je tokom osamnaest godina bio persona non-grata u toj zemlji).

Čingiz Abdulajev je autor 194 romana i novela, pripovetki, preko 440 publicističkih članaka, čiji je ukupan tiraž nadmašio 25 miliona primeraka na 28 jezika. Njegove knjige rasprodaju se za tren oka, a on sam, kao građanin Azerbejdžana, prema tvrđenjima „Književnom pregleda“, ulazi u prvih deset najčitanijih ruskih pisaca. Njegovo ime kao najčitanijeg pisca na ruskom jeziku uneto je u Ginisovu knjigu rekorda. Po njegovim delima napisano je 60 filmskih scenarija, snimljeno sedam filmova i dve serije. Početak njegovog književnog stvaralaštva utemeljili su istorijski roman i nekoliko lirskih priča. Prvi roman akcionog žanra „Plavi anđeli“ bio je tri godine zabranjen za štampanje od strane KGB-a, zbog navodno skrivenih informacija u njemu. Autorova novina se ogleda u tome što je on, još tokom života političkih rukovodioca pisao o njima, njihovim greškama i porocima. Gorbačov, Jeljcin, Putin, mnogi od njih se često pojavljuju pod drugim imenima, ali ih je lako prepoznati po njihovim procenama, delima, opisima i mnogim drugim karakterističnim crtama. Njegova dela su poučna i nose kosmopolitski karakter

Kako bismo shvatili veličinu dela Č. Abdulajeva, njegov odnos prema kriminalu i mafiji, citiraćemo autorovu misao iz predgovara knjige „Zakon podlaca“: „Želeo bih da skrenem pažnju čitaocima na jednu veoma važnu činjenicu. Ne treba mešati nacionalnu mafiju i narod, čiji su oni izrodi. Ne postoje loši narodi, to je jednostavna istina koji još mnogi nisu usvojili. Ako je potrebno, oni će se dogovoriti. Zapamtite, ostajteljudi koji poštuju čoveka zbog njegovog rada, uma, čestitosti; narod zbog njegove istorije, kulture, tradicije;i sebe zbog umeća da poštujete druge, ne spuštajući se na nivo primitivnog nacionalizma. Na kraju krajeva, teško je biti Čovek". ${ }^{3}$

Čuveni romani su: „,Plavi anđeli”,,Lov na čoveka”,,Stil podlaca” „Tri boje krvi",,Balkanski sindrom" „Oponenti Evrope” i mnogih drugi. U ro-

3 Č. Abudulajev, „Stil podlaca“, , Moskva, Eksmo. 1998, str. 11 
manu „,U očekivanju Apokalipse”on obrađuje temu raspada bivšeg Sovjetskog Saveza. Glavni junak njegovih dela postaje profesionalni obaveštajac Drongo, pripadnik starog i strogog režima. Drongo je odraz kolektiva, u njemu su oslikane crte karaktera i razmišljanja samog autora. Junak se pojavljuje pod raznim imenima. Drongo je simbolično ime, to je ptica iz jugo-istočne Azije koja označava hrabrost i veru u bolju budućnost. On donosi dobrobit mnogima, učestvuje u pronalaženju i uništavanju laboratorija za proizvodnju narkotika, rasvetljava mehanizme korupcije, izdaje i drugo, ali se istovremeno oseća bespomoćno posmatrajući raspad jedne od najvećih državana svetu, a samim tim i njegove političke ustanove - obaveštajnog aparata, koji je nekada nosio naziv KGB. Stari sistem je, po mišljenju junaka, bio dobar, ali su greške, trulež, ludilo komunističkog poretka dovele do rušenja imperije i pojave novih problema i prepreka u stvaranju nove, zasad još neodređene države.

On juriša ka cilju, odan prijateljima, sarkastičan, uvek ostajući svoj. Veran svojim idealima, uvek promišljen i precizan, i kao u svakom dobrom krimiću spreman da primeni silu kako bi pobedio zlo.

Pisanje Č. Abdulajeva karakteriše aktualnost, sveobuhvatnosti realni istorijski i politički događaji. Autor u svojim delima koristi citate genijalnih mislilaca i predstavnika svetske umetnosti, književnosti i kulture, razotkrivajući na taj načinprirodu ljudske duše i suštinu romana.

Rezimirajući gore navedeno, možemo istaći da azerbejdžanski detektivski roman karakteriše krajnja oštrina sukoba, zanimljiv siže, duboko istraživanje životnih problema, u kojem sposobni zločinac, bez obzira na snalažljivost, biva neminovno osuđen na poraz, a manje talentovani islednik, na pobedu.

U svojim delima autor je prikazao licemerje, prljavštinu, pohlepu i korumpiranost zločinačkog sveta,tj. mafije, koja dopire do samog vrha vlasti. Cilj mafije je samo jedan: prodati i izdati sve zbog sopstvene dobrobiti. $U$ osnovi kriminalističke priče nije samo zanimljiva psihološka igra, već i realna ljudska patnja, dubina ljudske duše, zahvaljujući čemu se detektivskom romanu, kao novom žanru, otvara put u veliku azerbejdžansku književnost.

Danas je Č. Abdulajev jedan od najpoznatijih svetskih autora detektivskih romana,koji je u svojim delima ujedinio političke događaje sa detektivskom istragom. Upravo zbog toga želeli bismo da se i srpski čitaoci, takođe, upoznaju sa njegovim stvaralaštvom. Sa tim ciljem, u najskorije 


\title{
Култура универзитета и филологија
}

vreme će Kulturni centar Azerbejdžana u Beogradu prevesti neka dela Čingiza Abdulajeva na srpski jezik i predstaviti ih srpskim čitaocima.

\author{
Lala Majidova \\ Azerbaijan University of Languages
}

\section{TEACHING NEW LITERARY GENRES AT THE AZERBAIJAN UNIVERSITY OF LANGUAGES}

\section{Summary}

The crime novel is one of the more productive branches of contemporary world literature, and as such, it contributes greatly to the theory of literature, extending its boundaries and possibilities. A modern detective novel was in the 40s of the XIX century in America and was conditioned by social-moral factors. This type of literary work has brought many new and interesting changes in Azerbaijani literature.

Chingiz Abdulayev is the creator of a political detective novel, based on real facts and events. Thanks to his works, 60 film scripts were written, seven films and two series were shot. The writing of Chingiz Abdullayev is characterized by actuality, comprehensiveness, real historical and political events. Today, Chingiz Abdullayev is one of the most famous authors of detective novels, and, that's why we want Serbian readers to meet with his creativity.

Key words: Azerbaijan, crime novel, dastana, Chingiz Abdullayev, Jamshid Amirov. 